\title{
Hyperplasia of lymphoid structures in the hypopharynx: a case report
}

Yuh Baba ${ }^{1,2,3^{*}}$, Yasumasa Kato ${ }^{2}$, Kaoru Ogawa ${ }^{3}$

\begin{abstract}
Introduction: Ectopic tonsillar tissue simulating a benign tumor of the hypopharynx is described in this report. Case presentation: We report the case of a 79-year-old Japanese woman with globus sensation. Because clinical observation revealed benign features, tumor tissue was laryngoscopically resected. From the pathological features, for example, existence of germinal center, lymphoid tissue, and crypt involving lymphoepithelial symbiosis, we diagnosed that the lesion was a hyperplasia of ectopic tonsillar tissue.
\end{abstract}

Conclusions: Although ectopic tonsillar tissue of the hypopharynx is relatively rare, it should be kept in mind during differential diagnosis.

\section{Introduction}

As many kinds of benign tumors, malignant tumors, and tumor-like lesions may occur in the hypopharynx (YB et al. unpublished data) it may be difficult to establish a clinical diagnosis. Here, we report a hypertrophied lymphoid case of the hypopharynx which was histologically diagnosed as the hyperplasia of ectopic tonsillar tissue. The tissue was removed surgically under general anesthesia. After the surgery, there was no obvious symptom of recurrence during, at least, the following year.

\section{Case presentation}

An otherwise healthy 79-year-old Japanese woman visited our department on $22^{\text {nd }}$ July 2008 . She had a medical history of chronic pharyngolaryngitis. The patient first visited her general practitioner because she had been aware of a foreign body sensation in her throat since December 2007. However, her condition did not improve, although she was treated by her general practitioner. She, therefore, visited our hospital in July 2008 to ask for a second opinion. When the first medical examination was performed by us using laryngopharyngeal fiberscopy, we observed a smooth mucosal swelling in the right pyriform recess but no vocal cord fixation (Figure 1). Computed tomography $(\mathrm{CT})$ revealed no space-occupying lesion in

\footnotetext{
* Correspondence: yuh_baba@hotmail.com

'Department of Otorhinolaryngology, Ohtawara Red Cross Hospital, 2-7-3

Sumiyoshi-cho Ohtawara City, Tochigi 324-8686, Japan

Full list of author information is available at the end of the article
}

the right pyriform recess (data not shown). From these observations, a preoperative diagnosis of a benign tumor was made. The swelling was restricted to the surface of the hypopharyngeal mucosa.

On 18 September 2008, the tissue was resected laryngoscopically under general anaesthesia and this sample was pathologically analyzed. We observed histological features of hyperplastic tonsil, for example, existence of germinal center, lymphoid tissue, and crypt involving lymphoepithelial symbiosis (Figure 2). An ectopic tonsil is tonsillar tissue that was developed in areas outside the palatine, tongue, pharynx, and Eustachian tube. Therefore, we diagnosed that the lesion was a hyperplasia of ectopic tonsillar tissue in the hypopharynx. The postoperative course was uneventful. Follow-up examinations showed there was no sign of recurrence of the swelling or complications during the following year.

\section{Discussion}

Although benign tumors such as papilloma or adenoma can generally occur in the hypopharynx, we found tonsillar tissue in this lesion. Ectopic tonsil is tonsillar tissue that was established at areas outside of the four major tonsil groups, which include the palatine tonsil, the lingual tonsil, the pharyngeal tonsil, and the tubal tonsil. The tonsil is a lymphoid tissue with a germinal center and crypt involving lymphoepithelial symbiosis. In our case we observed these criteria. 


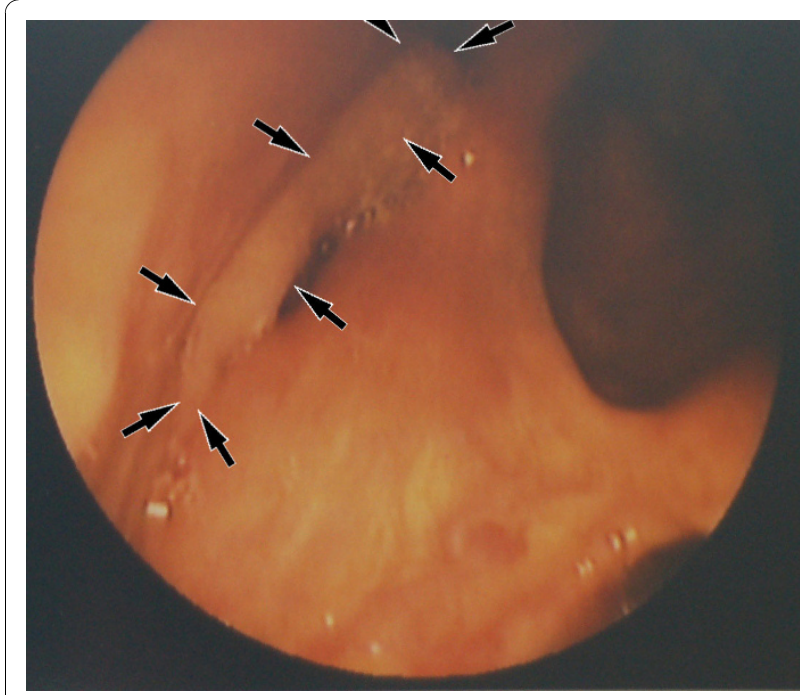

Figure 1 Location of the ectopic tonsillar tissue in the right pyriform recess of the hypopharynx.

The pathogenesis of our case is not clear. However, it is reported that ectopic tonsillar tissue in the nasal septum may be the result of a persistent infection [1]. Our patient had a medical history of chronic pharyngolaryngitis. Taken together, the patient's history of chronic laryngophatyngitis may have induced hyperplasia of the lymphoid tissues, in addition to the ectopic aberration.
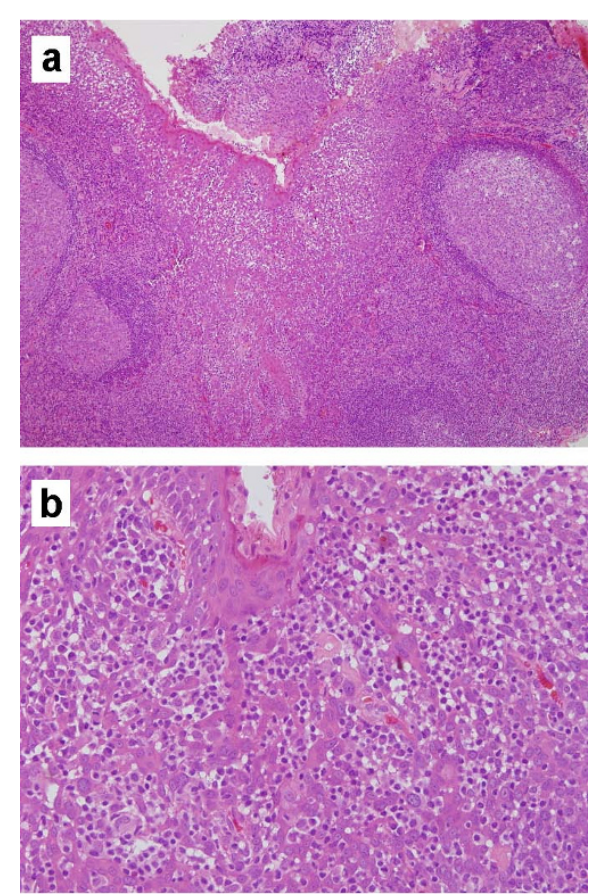

Figure 2 Pathological features. (a) Germinal center, lymphoid tissue, and crypt were noted. HE, X10 (b) Ectopic tonsillar tissue showing lymphoepithelial symbiosis in crypt. HE, X40.
Furthermore, we observed that a tonsillar cyst is located in the pyriform recess [2]. It was proposed that an oral cyst originated from an ectopic oral tonsil and obstruction of the crypt caused a cyst to form because of the persistent infection [3]. This proposal is consistent with our speculation with regard to the pathogenesis of this case. This resected tissue may be the precursor of the tonsillar cyst in the pyriform recess.

A few reports on ectopic tonsillar tissue have been published, showing that ectopic tonsillar tissues have been reported to be in the nasal septum [1], the floor of the mouth [3-6], the orbit [7], the ventral surface of the tongue $[3,4,6]$, the soft palate $[3,4]$, and the larynx [8]. A search of the literature suggests that ectopic tonsillar tissue of the hypopharynx is relatively rare. These lesions can be asymptomatic and easily overlooked, making them appear even rarer.

\section{Conclusions}

Although ectopic tonsillar tissue of the hypopharynx is relatively rare, it should be included in the differential diagnosis of patients who are aware of a foreign body sensation in their throats.

\section{Consent}

Written informed consent was obtained from the patient for publication of this case report and any accompanying images. A copy of the written consent is available for review by the Editor-in-Chief of this journal.

\section{Abbreviations \\ $\mathrm{CT}$ : computed tomography}

\section{Author details}

${ }^{1}$ Department of Otorhinolaryngology, Ohtawara Red Cross Hospital, 2-7-3 Sumiyoshi-cho Ohtawara City, Tochigi 324-8686, Japan. ${ }^{2}$ Department of Biochemistry \& Molecular Biology, Kanagawa Dental College, Yokosuka 2388580, Kanagawa, Japan. ${ }^{3}$ Department of Otorhinolaryngology, Head and Neck Surgery, Keio University, 35 Shinanomachi Shinjuku, Tokyo 160-0082, Japan.

\section{Authors' contributions}

$Y B$ assisted in the conception and design of the paper, and also helped in the acquisition, review and interpretation of the data. YK contributed towards data collection and drafting of the manuscript. KO was involved in conception of the paper, and in reviewing and finally approving the version of the manuscript to be published. All authors read and approved the final manuscript.

\section{Competing interests}

The authors declare that they have no competing interests.

Received: 2 April 2010 Accepted: 30 November 2010 Published: 30 November 2010

\section{References}

1. Furukawa M, Takeuchi S, Umeda R: Ectopic tonsillar tissue in the nasal septum. Auris Nasus Larynx 1983, 10:37-41.

2. Ramesar K, Albizzati C: Laryngeal cysts: clinical relevance of a modified working classification. J Laryngol Otol 1988, 102:923-925. 
3. Knapp MJ, Colonel L: Pathology of oral tonsils. Oral Surg Oral Med Oral Pathol 1970, 29:295-304.

4. Knapp MJ: Oral tonsils: location, distribution, and histology. Oral Surg Oral Med Oral Pathol 1970, 29:155-161.

5. Mogi K: Ectopic tonsillar tissue in the mucosa of the floor of the mouth simulating a benign tumour. Case report. Aust Dent J 1991, 36:456-458.

6. Patel K, Ariyaratnam S, Sloan P, Pemberton MN: Oral tonsils (ectopic oral tonsillar tissue). Dent Update 2004, 31:291-292.

7. Wolter JR, Roosenberg RJ: Ectopic lymph node of the orbit simulating a lacrimal gland tumor. Am J Ophthalmol 1977, 83:908-914.

8. Pellettiere EV, Holinger LD, Schild JA: Lymphoid hyperplasia of larynx simulating neoplasia. Ann Otol Rhinol Laryngol 1980, 89:65-68.

doi:10.1186/1752-1947-4-388

Cite this article as: Baba et al.: Hyperplasia of lymphoid structures in the hypopharynx: a case report. Journal of Medical Case Reports 2010 4:388.

\section{Submit your next manuscript to BioMed Central} and take full advantage of:

- Convenient online submission

- Thorough peer review

- No space constraints or color figure charges

- Immediate publication on acceptance

- Inclusion in PubMed, CAS, Scopus and Google Scholar

- Research which is freely available for redistribution

Submit your manuscript at www.biomedcentral.com/submit
C Biomed Central 